\title{
AGRICULTURAL DROUGHT ASSESSMENT OF POST MONSOON SEASON OF VAIJAPUR TALUKA USING LANDSAT8
}

\author{
Gaikwad S. V. ${ }^{1}$, Kale K.V. ${ }^{2}$ \\ ${ }^{1,2}$ Department of CS \& IT, Dr. Babasaheb Ambedkar Marathwada University, Aurangabad (M.S.) India. \\ ${ }^{1}$ Sandeep.gaikwad22@gmail.com, ${ }^{2}$ kvkale91@gmail.com.
}

\begin{abstract}
Drought is least understood natural phenomena and it has a direct impact on livelihood. The government bodies spend time and money for drought survey, but this process is a time consuming and challenging. Advantage of Geospatial Technology is that, it is helpful to understand the drought prone area and its severity level through satellite images. This research study was focused on Vaijapur taluka which is located at latitude of $19^{\circ} 40^{\prime}$ ' to $20^{\circ} 15^{\prime}$ ' north and longitude of $74^{\circ} 35^{\prime}$ to $75^{\circ} 00^{\prime}$ which comes under the scanty rainfall region. The annual rainfall of the region is 502.6mm which is below than an average of $750 \mathrm{~mm}$, so that it leads to the agriculture drought. In this study, Landsat 8 images of the year 2013 and 2014 were used for drought assessment in the post monsoon season. Landsat 8 has Operational Land Imager (OLI) and Thermal Infrared Sensor (TIRS) on board which provides 11 band data of the earth surface. The post monsoon season starts from October to December in India so that we have compared drought indices of two years. To do so OLI and TIRS images of Landsat 8 for the year 2013 and 2014 and ancillary data such as rainfall, temperature, sown area statistics have been used. The analysis of vegetation cover using NDVI, VCI, and SAVI indices demonstrate the impact of the post monsoon rainfall on agriculture field. According to the research study year 2013 was affected by agricultural drought.
\end{abstract}

Key Words: Drought Indices, Landsat 8, NDVI, SAVI, VCI.

\section{INTRODUCTION}

The manual drought survey and drought zone identification is a challenging and time consuming task. Remote sensing technology provides worldwide coverage to identify and monitor the drought hazard. The implementation of satellite image based drought indicators helps to understand drought impact zone [1,2]. Drought in Vaijapur taluka is not new, this region come under the scanty rainfall pattern. Scanty or irregular rainfall reduces soil moisture level [3,4,5]. Droughts occur due to failure of monsoons over a region. The drought is considered as most complex, but least understood natural phenomenon. The drought affects more people than any other natural disaster. Drought is a normal feature of climate and its recurrence is inevitable $[3,4,5,6]$. Drought is caused due to deficiency of water that depends on rainfall, which falls in uneven pattern across the country [7]. In India, post monsoon season start from mid of October to December month. Rabi season start from October to March, so that post monsoon rainfall is important for Rabi crops, like Wheat, Gram, Jawar. Such early or late commencement of sowing rains leads to large variations in year to year crop productivity $[8,9,10]$. Deficit rainfall leads to crop failures which creates shortage of food in the region. Currently, government bodies classify agricultural drought based on the ground observation of rainfall, crop health, aridity, and water level. It is very difficult to get real time observation of land surface and average drought conditions over the district $[11,12]$.
In India, National Agricultural Drought Assessment and Monitoring System (NADAMS) was established in 1986 by active participation of National Remote Sensing Agency (NRSC), Dept. of Space, Government of India, with the support of India Meteorological Department (IMD) and various state departments of agriculture. The Mahalanobis National Crop Forecast Centre (MNCFC) is a responsible for execution of NADAMS project, with the help of NRSC and Ministry of Agriculture (GOI) since 2012 [13]. Satellite based drought indices and meteorological data are used by MNCFC to evaluate a drought condition. NADAMS provide the information regarding agricultural drought and its severity level of state, district, and sub district level [14].

Remote sensing technology is an extremely useful to understand drought phenomena and it provides real time drought monitoring of an entire world [15,16,17,18]. The high resolution image data of the earth surface is helpful to study drought impact in small area like taluka, and village $[19,20,21]$. Several indices derived from satellite imagery like Normalized Difference Vegetation Index (NDVI), Vegetation Condition Index (VCI), Soil Adjusted Vegetation Index (SAVI) have been used for drought assessment and drought monitoring purpose [9, 15, 16, 17, 21]. The drought indices can be compute from low spatial resolution data of different sensors like the Moderate Resolution Imaging Spetroradiometer (MODIS) or Advanced Very High Resolution Radiometer (AVHRR). The low spatial resolution is a difficult to recognize drought severity level in village, block and taluka level [22]. Therefore, for a small regional analysis can be done with 
high resolution data. The Landsat 8 OLI and TIRS sensors provides high resolution data. For this research study, we have selected high resolution $30 \mathrm{~m}$ satellites images.

Sumanta Das et al. 2013, has worked on Landsat ETM+ data of Bankura district, Bengal, and he found that the satellite derived drought monitoring indices have also been correlated with precipitation index. The author has investigated that, the effects of vegetation stress condition and variability of rainfall on agricultural production [23].

Surendra Singh Chaudhary et al. 2012, has suggested that, the satellite based drought indicators like NDVI, VCI, SAVI, LST, and TCI are useful for analysis of drought condition in Bhopalgarh taluka, Jaipur, India. The author has used Landsat-7 ETM+ data for the analysis of drought affected area in pre and post monsoon of year 2000, 2002, 2010 etc [24].

Kundu and Dutta, 2011, stated that in their study, the vegetation conditions and crop growth depend upon entirely on rainfall. The less rainfall is a responsible for desertification process [25].

Ebrahimi et al. 2010, has been used NDVI and SAVI2 index to identify drought prone areas of Shirkooh basin of Iran. According to the author, the meteorological data and remote sensing data are important for accurate assessment of drought disaster [26].

The main objective of the research study was to assess the drought severity in Vaijapur taluka using satellite based drought indices.

\section{STUDY AREA AND DATASET}

Vaijapur taluka comes in scanty rainfall region of Maharashtra state, India and situated on the latitude of $19^{\circ} 40^{\prime}$ to $20^{\circ} 15^{\prime}$ north and longitude of $74^{\circ} 35^{\prime}$ to $75^{\circ} 00^{\prime}$ east, covering an area of approximately 1510.5 sq. km which is shown in figure 1 . The study area fall in the Survey of India Toposheet No. $47 \mathrm{I} / 9,47 \mathrm{I} / 13$, and $46 \mathrm{~L} / 16$. According to the census of 2001, the total population of the study area was 259601. The economy of the Vaijapur taluka is based on agriculture sector.

For this research study, we have collected rainfall and temperature data from tehsil office and the sown area report was taken from the agriculture office of Vaijapur. The average rainfall of the study area is $506.2 \mathrm{~mm}$. The significant amount of rainfall happen during the post monsoon season in which agriculture field and rangeland vegetation depend.

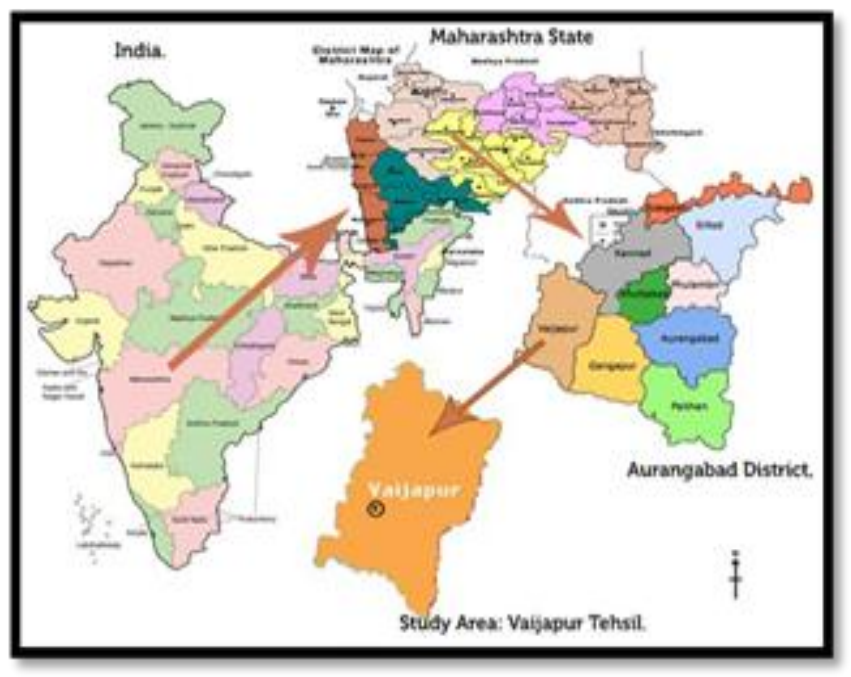

Figure 1. Study Area. Source [27, 28, 29]

Landsat 8 OLI and TIRS data were obtained from the U.S. Geological Survey Earth Resources Observation and Science (EROS) Centre Landsat archive. The Landsat archive consists processed data of Level 1 Terrain corrected (L1T) level defined in the GeoTIFF file format in the Universal Transverse Mercator (UTM) map projection. Landsat 8 satellite has OLI and TIRS sensor on board to capture earth's surface with 16 days temporal resolution. The Operational Land Imager (OLI) sensors have total 9 spectral bands in which include new band such as deep blue band $(0.433-0.453 \mu \mathrm{m}) 30 \mathrm{~m}$ for coastal/aerosol studies and short-wave infrared band 9 $(1.360-1.390 \mu \mathrm{m}) 30 \mathrm{~m}$ for cirrus cloud detection. The Thermal Infrared Sensor (TIRS) sensor, includes two thermal bands which are Band 10 - Thermal Infrared (TIRS) 10.60 - 11.19 Micrometer and Band 11 - Thermal Infrared (TIRS) 11.50 - 12.51 Micrometer wavelength. In the present study, we have compared various indices which are derived from Landsat 8 satellite images of the post monsoon season of year 2013 and 2014. We have obtained total 6 Landsat 8 images for research study which has cloud cover $<80 \%$. Information about Landsat 8 dataset is shown in Table- 1 .

Table-1. Landsat 8 dataset used for research study.

\begin{tabular}{|l|c|l|l|}
\hline \multicolumn{4}{|c|}{ Landsat 8 Dataset } \\
\hline Sr. No & Path/Row & Year 2013 & Year 2014 \\
\hline 1 & 147-46. & $\begin{array}{l}\text { October, } \\
\text { November, } \\
\text { December }\end{array}$ & $\begin{array}{l}\text { October, } \\
\text { November, } \\
\text { December }\end{array}$ \\
\hline
\end{tabular}

\section{METHODOLOGY}

The methodology was prepared on the basis of literature survey which is shown in figure 2. Drought indices were calculated using a spatial model tool included in ERDAS Imagine 2014 evaluation copy. For the map preparation, we have used ArcGIS 10.2.2 software. For this study, we have gathered various data types such as temperature, rainfall, sown data and satellite data. The meteorological drought is analyzed based on rainfall and temperature data. We have 
downloaded geometric rectified Landsat 8 satellite images of the month October, November, December of post monsoon season of 2013-2014.

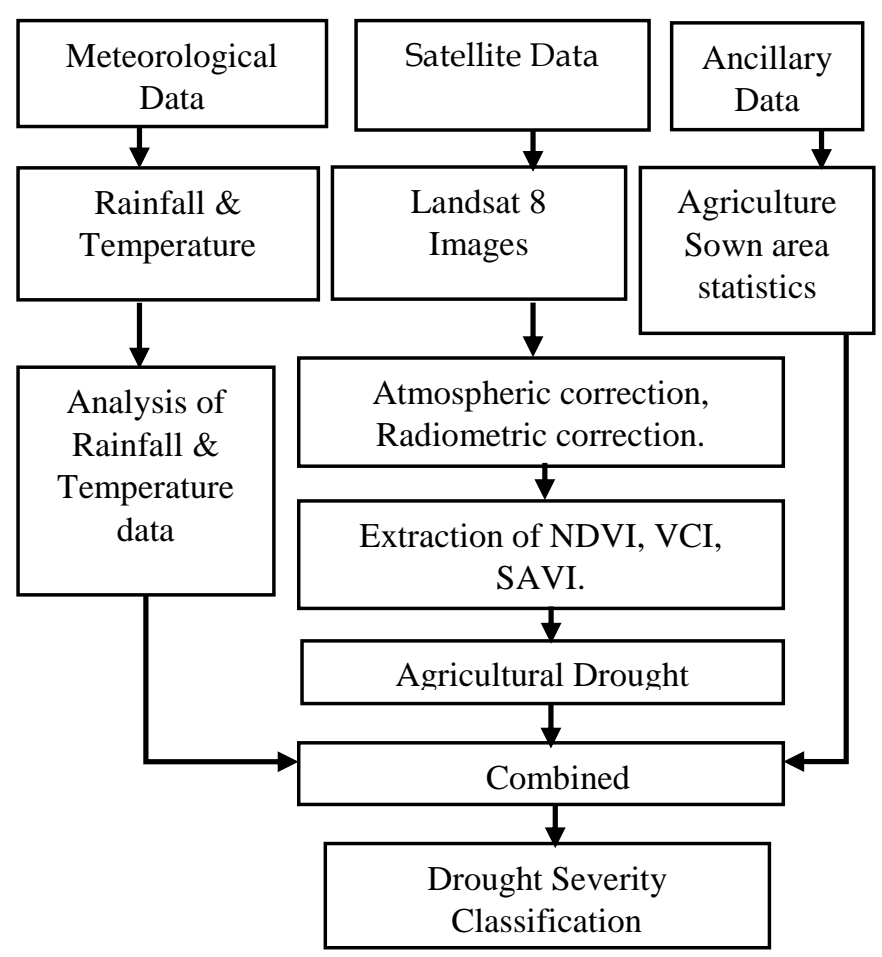

Fig-2. Workflow of Methodology

\subsection{Pre-Processing of Landsat 8 Data}

Atmospheric correction is an essential to compare multitemporal scene, because digital number are substituted by surface reflectance [30]. ATCOR3 is an extension of ERDAS Imagine 2014 and PCI Geomatica 2014 software, which is used for haze removal and atmospheric topographic correction operation. The atmospheric error and haze effect occur in an image because of scattering and absorption of light by the earth's atmosphere. The ATCOR algorithm works with a database of atmospheric correction function stored in ATCOR library [31]. It includes various atmospheric parameters such as pressure, fog, air temperature, humidity; aerosol types; ground elevations from 0 to $2.5 \mathrm{~km}$ above sea level; solar zenith angle ranging from 0 to 70 degrees. The database also covers visibilities (surface Meteorological range) from $5 \mathrm{~km}$ to $120 \mathrm{KM}$, values, can be extrapolated down to $4 \mathrm{~km}$ and up to $180 \mathrm{~km}$ using ATCOR sensor calibration [32, 33]. ATCOR module provides various functionality like Atmospheric correction, Haze removal, Land Surface Temperature calculation. It calculates a ground reflectance image in each spectral band the first step to assumes as isotropic (Lambert) reflectance law, neglecting the neighbourhood of each step accounts for the influence of the neighbouring background [34].

\section{SATELLITE BASED DROUGHT INDICATORS}

The agricultural drought derived from vegetation indices like NDVI, VCI, and SAVI from Landsat band data. Drought Severity classification made by combining meteorological, satellite, ancillary data. A major consideration for development of remote sensing for drought assessment and disaster reduction is an extent to which operational user can rely on a continued supply of data [35]. The total agricultural cropland was $129193.6 \mathrm{H}$. The sown area was $23801 \mathrm{H}$ in year 2013 and $23401 \mathrm{H}$ in year 2014. The rainfall affects in sown area, only $8 \%$ crop land comes under sown activity as shown in Chart- 8 . Drought indicator has a range which is helpful for classification of severity of drought, which is shown in table-2.

Table-2. Shows satellite drought indicator [10].

\begin{tabular}{|c|c|c|c|c|}
\hline $\begin{array}{c}\text { Drought } \\
\text { Index }\end{array}$ & Range & $\begin{array}{c}\text { Norma } \\
1\end{array}$ & $\begin{array}{c}\text { Severe } \\
\text { Drought }\end{array}$ & $\begin{array}{c}\text { Healthy } \\
\text { Vegetation }\end{array}$ \\
\hline NDVI & $\begin{array}{c}-1 \text { to } \\
+1\end{array}$ & $\begin{array}{c}\text { Locati } \\
\text { on } \\
\text { based }\end{array}$ & -1 & +1 \\
\hline VCI & $\begin{array}{c}0 \text { to } \\
100 \%\end{array}$ & $50 \%$ & $0 \%$ & $100 \%$ \\
\hline SAVI & $\begin{array}{c}-1 \text { to } \\
+1\end{array}$ & 0 & -1 & +1 \\
\hline
\end{tabular}

\subsection{Normalized Difference Vegetation Condition index (NDVI)}

The NDVI was calculated using Infrared channel (0.78-0.90 $\mu \mathrm{m})$ and Red channels of visible region $(0.63-0.69 \mu \mathrm{m})$. The vegetation reflects more in the infrared band. The NDVI can be computed using equation (1).

$$
N D V I=\frac{(N I R-R E D)}{(N I R+R E D)}
$$

where, NIR $=$ near infrared band, $\mathrm{RED}=$ Red band;

The most of the visible light is absorbed by healthy vegetation and it reflects NIR light [36]. Unhealthy vegetation reflects more visible light and less infrared light. Spatial model for NDVI was prepared in ERDAS Spatial Model maker tool.

\subsection{Vegetation Condition Index (VCI)}

Kogan (1990) developed the Vegetation Condition Index (VCI) using the range of NDVI composition. The severity of agricultural drought can be assessed by VCI [8]. It is defined as in equation (2).

$$
V C I=\frac{(\text { NDVI-NDVImin })}{(\text { NDVImax }+ \text { NDVImin })} * 100
$$

where, the NDVI is the actual value of NDVI. The NDVImax and NDVImin are calculated from NDVI composites of each month. The vegetation health is measured in percent. The $100 \%$ value of VCI indicates that healthy vegetation and value is less than $50 \%$ indicate the different degree of drought severity. The VCI is sensitive to vegetation [36]. 


\subsection{SOIL ADJUSTED VEGETATION INDEX (SAVI)}

The SAVI index was developed as a modification of the NDVI. The SAVI is used to correct the influence of soil brightness [10]. It is shown in equation (3).

$$
S A V I=\frac{(N I R-R E D)}{(N I R+R E D+L)} *(1+L)
$$

where, NIR is the near Infrared band, RED is the red band, and $\mathrm{L}$ is the soil brightness correction factor. Generally, $\mathrm{L}=0.5$ works well in most situations and it is the default value used for calculation.

\section{METEOROLOGICAL DATA AND SOWN} AREA STATISTICS

The Vaijapur taluka has received $500.6 \mathrm{~mm}$, and $566.7 \mathrm{~mm}$ in the year 2013 and 2014 respectively. The October to December month is the duration of the post rainy season in India, this period is known as the North-East monsoon season. The rainfall received during this period is $13 \%$ to $33 \%$ of annual rainfall shown in chart- 1 . The temperature in the region was beginning to high up in the mid of October and later starts falling rapidly in the post monsoon season which is shown in chart-2. According to the agriculture official report, the distribution of rainfall varies due to vegetation cover so that North-West zone was highly affected by drought. The Ground water level was below the 300-600 feet so that farmers cannot use well and borwell water for agriculture purpose because it is very cost effective. An entire agriculture sector of the study area is based on seasonal rainfall. The total area of Vaijapur taluka is a 159390 Hectare $(\mathrm{H})$ including agricultural cropland 129193.6H. The sown area was $23801 \mathrm{H}$ in year 2013 and $23401 \mathrm{H}$ in Year 2014. The rainfall affects in sown area, only $8 \%$ crop land comes under sown activity. This is shown in Chart- 3.

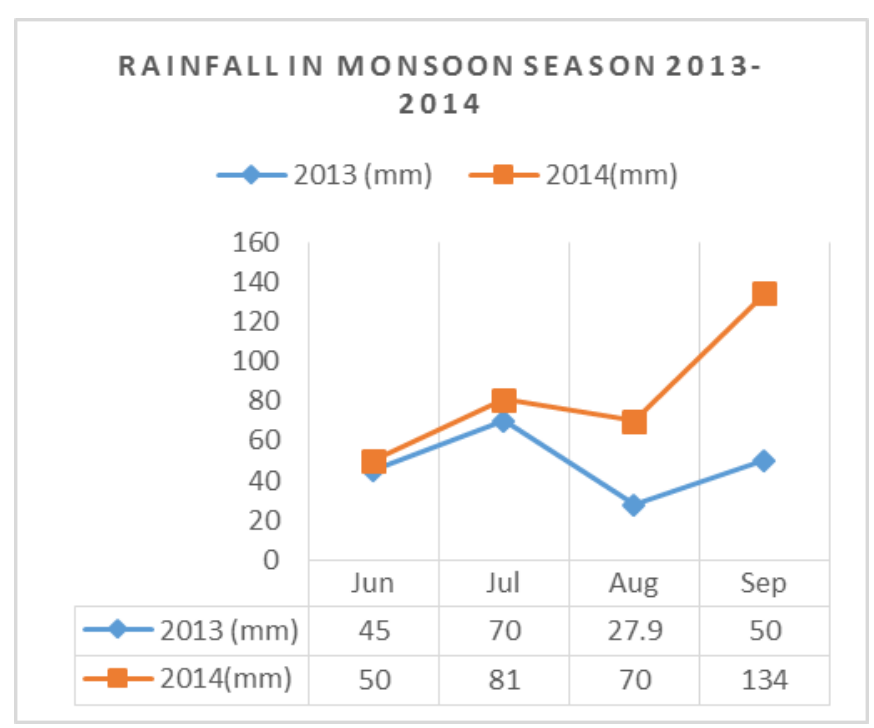

Chart-1 Rainfall for year 2013 and 2014.

\section{MEAN TEMP OF MONSOON SEASON 2013-2014}

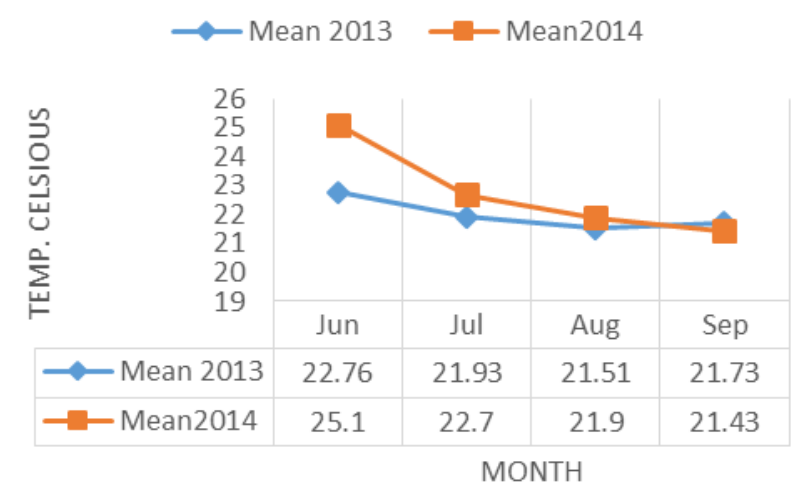

Chart-2. Temperature of Vaijapur in Year 2013-2014.

Vaijapur Sown area Rabi Season 2013 \& 2014

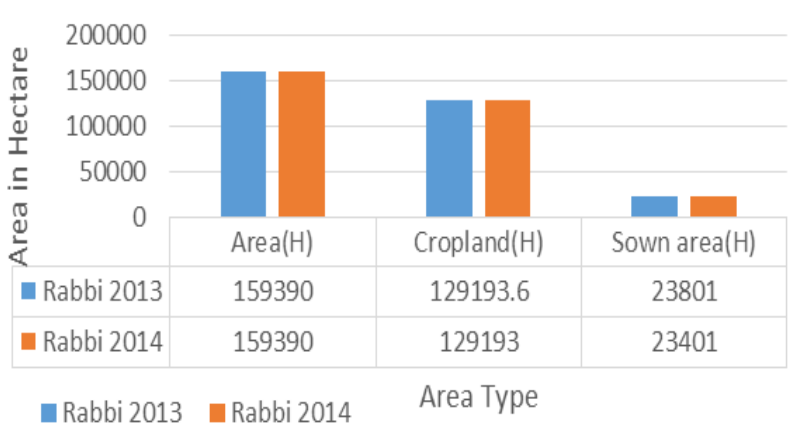

Chart- 3. Sown area of Vaijapur of year 2013-2014.

\section{RESULT AND DISCUSSION}

The analysis of Landsat 8 images of post monsoon of the year 2013 and 2014 has revealed drought severity condition in study area. The spatial distribution of NDVI index for the month of October to December is shown in chart- 4.

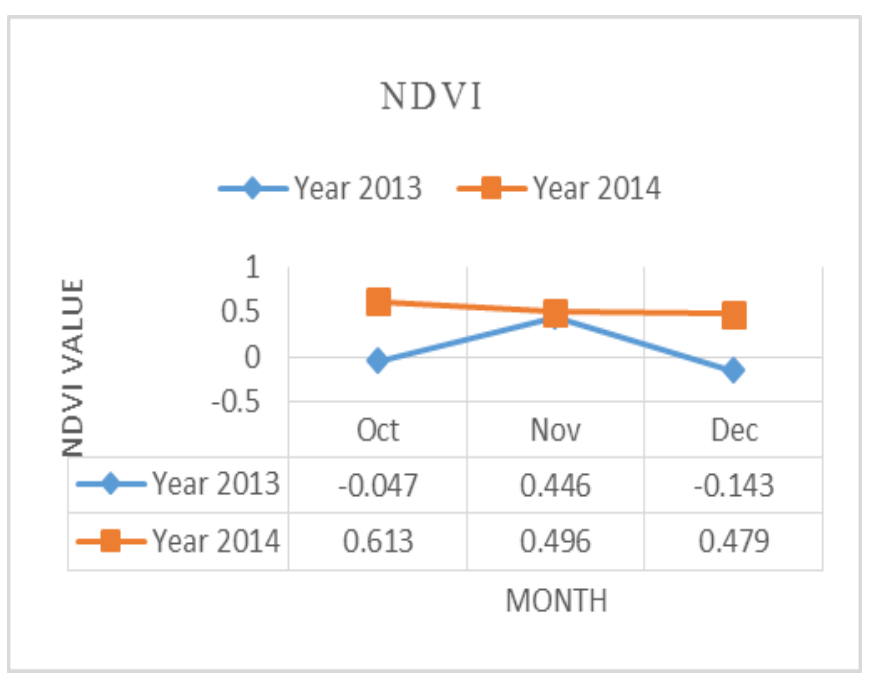

Chart- 4. NDVI of year 2013 and 2014. 


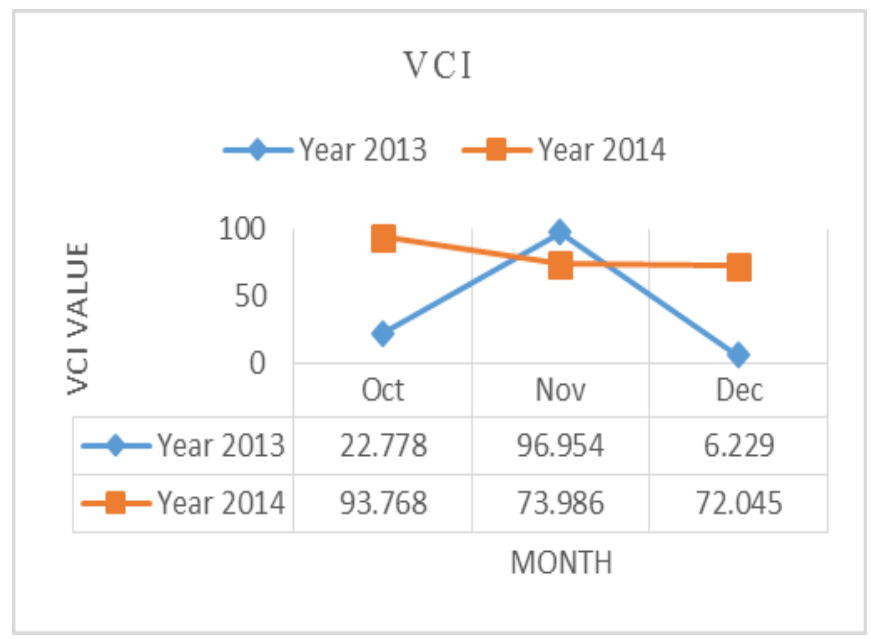

Chart- 5. VCI of year 2013 and 2014.

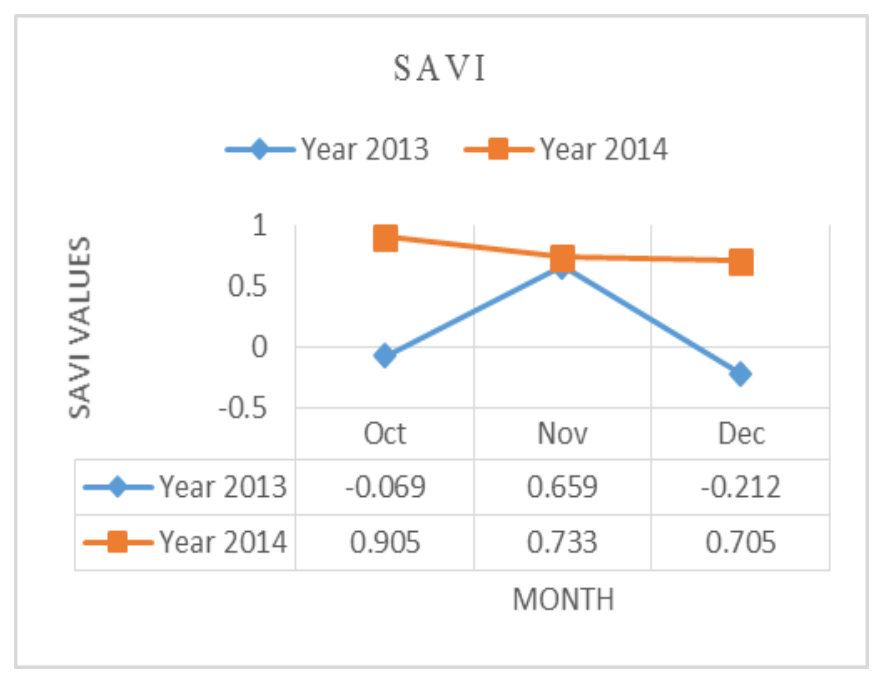

Chart- 6. SAVI of year 2013 and 2014.

The NDVI of October season was -0.047 in the year 2013 which was very less than 2014. The NDVI value of October month in the year 2013 was very low, but in November month it was 0.446 , it is indicating that, the sown crop has grown in the farm land. In December 2013, the NDVI value was -0.143 , it indicates that crop failure. It means that the deficiency soil moisture is responsible for crop failure. The Vaijapur taluka has received very less rainfall in November, and December 2013, which is not enough to maintain health of the crop. The NDVI has affected by rainfall so that changes in vegetation can be seen in Chart- 4 . The NDVI value of October 2013-2014 was better than November and December 2013-2014. In the October, November, December the value of NDVI was $0.613,0.496,0.479$ respectively. It shows that, the normal condition of drought in the year 2014. The vegetation health was degraded in October 2013 and December 2013 so that these months were affected by extreme drought which is shown in fig-3.

The VCI index can be used for analysis of vegetation health. The value of the VCI index was 96.954 in November 2013 and 6.229 in December 2013 which is shown in the chart-5. The VCI value of the 2013 is lower than the year 2014, due to less rainfall received in the post monsoon season of 2013.
The fig-4 indicates that, the health of crop was degraded due to insufficient soil moisture present in the soil.

The SAVI index was used to study soil moisture, which is the most important factor to maintain crop health. The value of SAVI index is positive, then the area is less affected by drought, if difference value is less than zero then the area is highly affected by drought. Figure 14 represents that, the result of SAVI index. The value of SAVI is also varies due to rainfall anomaly. In October, November, December 2014, the value of SAVI index was $0.905,0.733$, and 0.705 , which is showing that the normal condition of drought in the year 2014.

The drought monitoring systems were developed by different agencies which are based on very low spatial resolution images. That system is good for district and state level monitoring, but it is unusable to understand drought condition of small administrative boundary like block and villages. The advantage of Landsat 8 data is that, it has $30 \mathrm{~m}$ resolution, which is important to work on small areas. This research is helpful for government agencies and government disaster planning bodies to create a drought mitigation plan. 

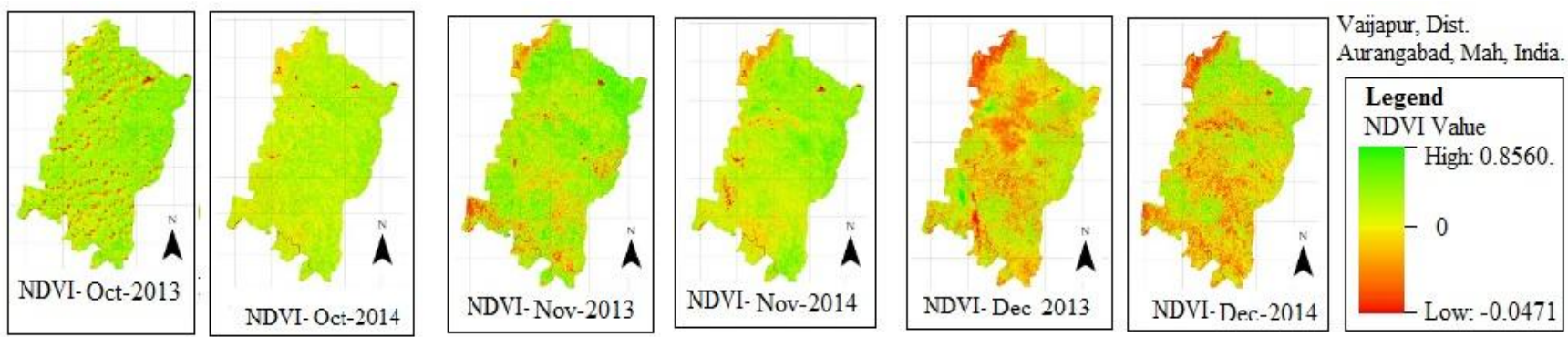

Fig-3. NDVI of year 2013-2014.
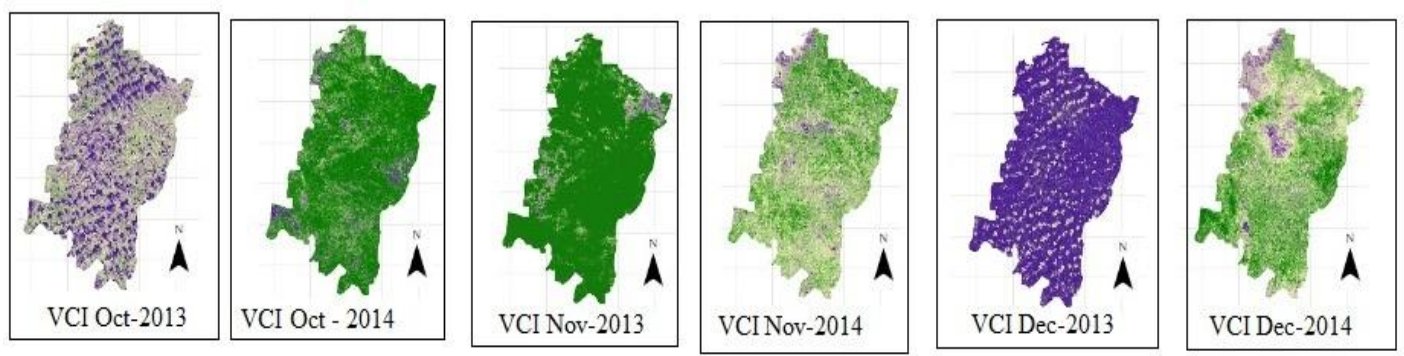

Vaijapur, Dist. Aurangabad, Mah, India.

Fig-4. VCI of year 2013-2014.
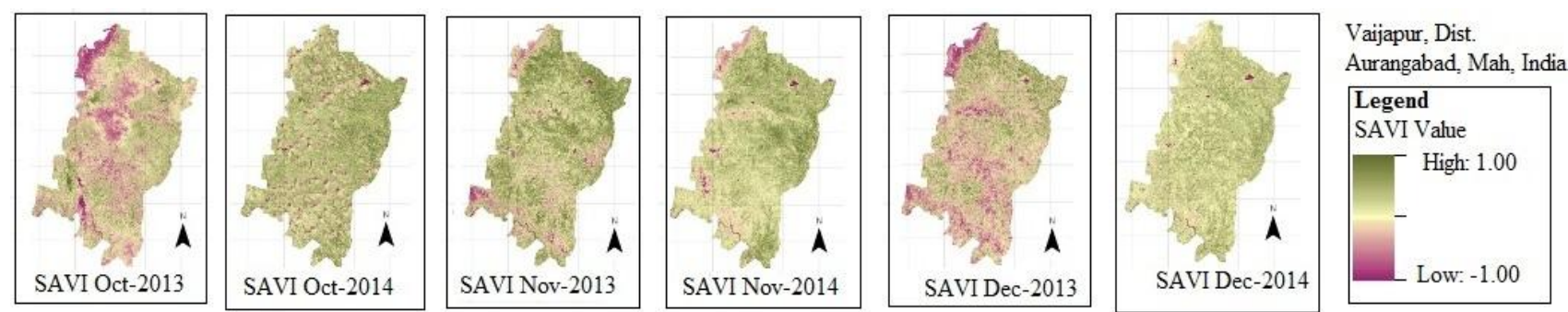

Fig-5. SAVI of year 2013-2014.

\section{CONCLUSION}

The objective of the research study was to identify drought severity level using satellite based drought indicators and to see how appropriately drought risk areas can be delineated by integration of satellite images, meteorological and ancillary data.

The value of NDVI is -0.143 and VCI $6.229 \%$ lower in the year 2013, it is indicated that crop health is very critical. The value of SAVI was less than 0.5 throughout the season, i.e. show that, the soil moisture was not enough to maintain crop health in the study area.

Also in our study, it was also found that, the temporal variations of NDVI are closely linked with VCI, and SAVI indices. The slope of all indicators follows the same pattern. The delay of the rainfall during post monsoon season affects the sowing operation of Rabi season, in 2014. The sown area in Rabi season was decreased by $400 \mathrm{H}$ compared to 2013. Deficit rainfall is the main cause to lower down sown area in Rabi season.

Taluka has faced scarcity of water in the year 2013-2014 because it has received below average annual rainfall. Hence, it is concluded that, the study area was affected by severe drought in year 2013 and normal drought in 2014.

\section{ACKNOWLEDGMENTS}

The authors would like to acknowledge and thanks to University Grants Commission (UGC), India for granting UGC SAP (II) DRS Phase-I \& Phase-II F. No. 3-42/2009 \& 4-15/2015/DRS-II for Laboratory facility to Department of Computer Science and Information Technology, Dr. Babasaheb Ambedkar Marathwada University, Aurangabad, Maharashtra, India and financial assistance under UGC BSR Fellowship for this work.

The author is thankful Vaijapur Taluka office and the Agricultural office for providing meteorological and sown area data. The author is also thankful to USGS for providing all the satellite images requested by the author on their Timeline.

\section{REFERENCES}

[1] Singh R. P. et al. "Vegetation and temperature condition indices from NOAA AVHRR data for drought monitoring over India," International Journal of Remote Sensing, Vol.24, No. 22, pp.4393-4402, 2003. DOI: 10.1080/0143116031000084323

[2] Hao Sun, Xiang Zhao, Yunhao Chen, Adu Gong \& Jing Yang. 2013. "A new agricultural drought monitoring index combining MODIS NDWI and day-night land surface temperatures: a case study in China," International Journal of Remote Sensing, Vol. 34, 
No.24, pp. 8986-9001, 2003. DOI: 10.1080/01431161.2013.860659

[3] Mishra A.K. et al. 2005. "Spatial and temporal drought analysis in Kansabati river basin, India," International River Basin Management Vol. 3, No. 1, pp 3141,2005.

[4] Bhuiyan C., "Desert vegetation during droughts: response and sensitivity," The International Archives of the Photogrammetry Remote Sensing and Spatial Information Sciences. Beijing Vol. 37(B8). pp. 907912, 2008.

[5] Murthy C. S. et al., "Spatial and temporal responses of different crop-growing environments to agricultural drought: a study in Haryana state, India using NOAA AVHRR data," International Journal of Remote Sensing, Vol. 30 No.11, pp.2897-2914,2008.

[6] Osman Orhan, et al., "Use if Landsat Surface Temperature and vegetation Indices for Monitoring Drought in the Salt Lake Basin Area, Turkey," The Scientific World Journal, Article ID 1429. pp. 1-11, 2014.

[7] Himanshu S. K. et al., "Monitoring of Drought using Satellite Data," International Research Journal of Earth Sciences, Vol. 3, No. 1, pp. 66-72, 2015.

[8] Kogan F.N., "Remote sensing of weather impacts on vegetation in non-homogeneous areas," International Journal of Remote Sensing, Vol.11 No.8, pp.14051419, 1990.

[9] Kasturirangan K., "Ground based measurements for Interpretation of vegetation Indices over developing Countries," Advance Space Res. Vol. 17 No.8, pp.3140, 1996.

[10] Thenkabail et al. The use of remote sensing data for drought assessment and monitoring in southwest Asia. Colombo, Sri Lanka: International Water Management Institute (IWMI) v, 25p. 2004, (IWMI Research Report 085)URL

http://www.iwmi.cgiar.org/Publications/IWMI_Researc h_Reports/PDF/PUB107/RR107.pdf (retrieved on May $15,2015)$.

[11] Wilhite D.A., "Drought as a natural hazard. In International Perspectives on Natural Disasters: Occurrence," Mitigation, and Consequences. Edited by J.P. Stoltman, J. Lidstone, and L.M. Dechano. Kluwer Academic Publishers, Dordrecht, Netherlands. pp. 147162, 2004.

[12] Wilhite D.A., "The enigma of drought. Drought Assessment, Management, and Planning: Theory and Case Studies," Kluwer Academic Publishers, Boston, Ma. pp. 3-15, 1993.

[13] MNCFC: Mahalanobis National Crop Forecast Center(MNCFC) [Internet]; Delhi; [Cited 2015 May 05] Available from: http://www.ncfc.gov.in/

[14]NRSC: National Remote Sensing Center Earth Observation Applicatio for Agricultural Drought Assessment[Internet];[Cited 2015 May 05] Available from:

http://nrsc.gov.in/Earth_Observation_Applications_Agr iculture_Drought_Assessment.html

[15] Palmer W. C, "Meteorological Drought. Research,"
Paper No. 45, U.S. Department of Commerce Weather Bureau, Washington, D.C. pp. 58. 1965.

[16] Tucker, C.J., J.R.G. Townshend, and T.E. Goff. African land cover classification using satellite data. Science, Vol. 9227, Vol. 4685, pp. 369-375, 1985.

[17]Cai, G., Du, M., and Liu, Y. "Regional drought monitoring and analysing using MODIS data - case study in Yunnan Province," In Computer and Computing Technologies in Agriculture IV. Edited by D. Li, Yande Liu, and Y. Chen. Springer, Boston. pp. 243-251, 2011.

[18]Liang Sun et al. "Monitoring surface soil moisture status based on remotely sensed surface temperature and vegetation index information," Agricultural and Forest Meteorology, Vol.166-167, pp. 175-187, 2012

[19] Ghulam A., Qin Q., and Zhan Z., "Designing of the perpendicular drought index," Environmental Geology. Vol.52, No.6, pp.1045-1052, 2007. doi:10.1007/s00254-006-0544-2.

[20] Rhee, J. et al., "Monitoring agricultural drought for arid and humid regions using multi-sensor remote sensing data," Remote Sensing Environment Vol.114, No.12, pp.2875-2887, 2010.

[21] Wang P., Li, X., Gong, J., and Song, C. 2001. "Vegetation temperature condition index and its application for drought monitoring," In Geoscience and Remote Sensing Symposium, IGARSS'01, IEEE. 2001.

[22] Peled E. et al., "Technical Note: Comparing and ranking soil drought indices performance over Europe, through remote sensing of vegetation," Hydrology Earth Syst. Sci., Vol.14, pp.271-277, 2010. doi:10.5194/hess-14-271-2010.

[23] Sumanta Das et al., "Geospatial assessment of agricultural drought (A Case Study of Bankura District, West Bengal)," International Journal of Agricultural Science and Research (IJASR) ISSN 2250-0057 Vol. 3, No.1, pp.1-28, 2013.

[24] Surendra Singh Chaoudhary, P. K. Garg, S. K. Ghosh., "Mapping of agriculture drought using Remote Sensing and GIS," International Journal of Scientific Engineering and Technology, Vol 1, No.4, pp.149-157, 2012.

[25] Dutta D, N.R. Patel, A. Kundu., "Analysing the performance of auto regressive integrated moving average (ARIMA) model for predicting agricultural productivity in eastern Rajasthan," Res. J. Agric. Sci., Vol . 2, pp. 555-559, 2011.

[26] Ebrahimi M, et al. "Remote sensing for drought assessment in arid regions (A case study of central part of Iran, "Shirkooh-yazd").Wagner W., Székely, B. (eds.): ISPRS TC VII Symposium - 100 Years ISPRS, Vienna, Austria, IAPRS, Vol. XXXVIII, Part 7B. 2010.

[27] Map of India. retrieved on May 052015 http://www.imagekb.com/india-map

[28] Map of Maharashtra State: Maharashtra State Chemists and Druggist Association; retrieved on May 052015 Available From: http://www.mscda.net/map.html

[29] Map of Aurangabad District Map Aurangabad: Collector Office; retrieved on May 052015 http://www.aurangabad.nic.in/newsite/index.htm 
[30] Roy D. P. et al., "Conterminous United States demonstration and characterization of MODIS-based Landsat ETM + atmospheric correction," Remote Sensing of Environment Vol.140 (2014), pp.433-449, 2014.

[31] Richter R., "Correction of atmospheric and topographic effects for high spatial resolution satellite imagery," International Journal of Remote Sensing, Vol. 18, No.5, pp.1099-1111, 1997. DOI: 10.1080/014311697218593

[32] Richter, R., "A spatially adaptive fast atmospheric correction algorithm," International Journal of Remote Sensing, Vol.17, pp.1201-1214, 1996.

[33] Richter, R., "Atmospheric correction of satellite data with haze removal including a haze/clear transition region," Computers \& Geosciences, Vol.22, pp.675681, 1996.

[34] Vanhellemont Q, Ruddick K., “Advantages of high quality SWIR bands for ocean colour processing: Examples from Landsat-8," Remote Sensing of Environment, Vol.161(2015), pp.89-106, 2015.

[35] Dan-Xia Song et al., "Use of Landsat and Corona data for mapping forest cover change from the mid-1960s to 2000s: Case studies from the Eastern United States and Central Brazil," ISPRS Journal of Photogrammetry and Remote Sensing, Vol.103 (2015), pp. 81-92, 2015.

[36] A.L. Yagci et al., "The effect of land-cover change on vegetation greenness-based satellite agricultural drought indicators: a case study in the southwest climate division of Indiana USA," International Journal of Remote Sensing, Vol. 34, No.20, pp. 6947-6968, 2013. DOI: $10.1080 / 01431161.2013 .810824$ 